
FIT(PATOLOGI
Volume 11, Nomor 4, Agustus 2015
I N DONESIA
Halaman 113-120
ISSN: 0215-7950
DOI: $10.14692 /$ jif.11.4.113

\title{
Identifikasi Nematoda Puru Akar, Meloidogyne graminicola, pada Tanaman Padi di Jawa Barat
}

\section{Identification of Root Knot Nematodes, Meloidogyne graminicola, on Rice in West Java}

\author{
Mochamad Yadi Nurjayadi, Abdul Munif*, Gede Suastika \\ Institut Pertanian Bogor, Bogor 16680
}

\begin{abstract}
ABSTRAK
Nematoda puru akar (NPA), Meloidogyne spp. merupakan salah satu patogen penting pada tanaman padi di beberapa wilayah di dunia. Informasi mengenai NPA pada tanaman padi di Jawa Barat penting untuk diketahui karena Jawa Barat merupakan salah satu sentra produksi padi nasional yang paling besar. Tujuan penelitian ialah menentukan keberadaan dan mengidentifikasi NPA pada tanaman padi di wilayah Jawa Barat. Sampel tanaman padi diambil dari 7 kabupaten penghasil padi di Jawa Barat. Gejala khas tanaman padi yang terinfeksi oleh Meloidogyne spp. ialah pertumbuhan tanaman terhambat dan bagian akarnya terbentuk puru. Hasil pengamatan di lapangan menunjukkan bahwa NPA ditemukan menginfeksi tanaman padi di beberapa daerah di wilayah Bogor, Cirebon, dan Sukabumi. Semua stadium perkembangan NPA yang meliputi telur; larva instar ke-2, 3, dan 4; betina dewasa dan jantan dewasa ditemukan di dalam jaringan akar padi. Berdasarkan pengukuran panjang tubuh, panjang stilet, lebar badan maksimum, dan panjang ekor larva instar ke-2 maupun morfologi pola perineal betina dewasa dibuktikan bahwa nematoda pada akar padi ialah M. graminicola.
\end{abstract}

Kata kunci: Morfologi, morfometrik, pola perineal.

\section{ABSTRACT}

Root knot nematodes (RKN), Meloidogyne spp. is one of the most important rice pathogen in some regions in the world. Information of RKN on rice plants in West Java is very important because West Java is one of the largest national rice production center. The purpose of this study was to determine and identify the presence of Meloidogyne spp. on rice plants in West Java. Rice plant samples were taken from 7 rice-growing districts in West Java. Typical symptoms of infected rice plants by Meloidogyne spp. are stunting and the formation of root galls. RKN was found to infect rice plants in several areas in Bogor, Cirebon, and Sukabumi. All stadia of the RKN development which include eggs, second, third, and fourth stage jeveniles, adult females and males were found inside the rice root tissues based on nematode staining observation. Morphometric measurements of the body and stylet length, maximum body width, length of the second stage juveniles, and female perineal pattern, indicated that Meloidogyne species found was M. graminicola.

Key words: Morphology, morphometric, perineal pattern.

*Alamat penulis korespondensi: Departemen Proteksi Tanaman, Fakultas Pertanian, Institut Pertanian Bogor, Jalan Kamper, Kampus Darmaga IPB, Bogor 16680

Tel: 0251- 8629364, Faks: 0251- 8629362, Surel: munif73@gmail.com 


\section{PENDAHULUAN}

Meloidogyne spp. yang dikenal sebagai nematoda puru akar merupakan nematoda parasit penting yang memiliki distribusi yang luas dan mampu menginfeksi berbagai macam tanaman pertanian. Salah satu tanaman budidaya yang dapat terserang oleh nematoda ini ialah padi. Serangan nematoda puru akar (NPA) pada tanaman padi dapat mengakibatkan kehilangan hasil yang bervariasi bergantung pada tingkat kepadatan populasi nematoda. Beberapa hasil laporan menyatakan bahwa kehilangan hasil yang disebabkan oleh NPA pada tanaman padi berkisar 20-80\% di berbagai kawasan Asia Selatan dan Tenggara (Erlan 1993; Padgham et al. 2004; Pokharel et al. 2007; Jaiswal et al. 2011).

Gejala umum tanaman padi yang terinfeksi NPA di antaranya ialah daun menguning, pertumbuhan tanaman terhambat, tanaman menjadi layu dan puru terbentuk pada akar (Dutta et al. 2012). Spesies NPA yang mampu menginfeksi akar padi bukan hanya satu spesies saja melainkan beberapa spesies Meloidogyne. Beberapa laporan menyatakan bahwa spesies NPA yang dapat menyerang tanaman padi di antaranya ialah $M$. graminicola, $M$. incognita, M. javanica, $M$. arenaria, $M$. oryzae, $M$. salasi, dan M. triticozae (Bridge et al. 2005; Pokharel et al. 2007; Nguyen et al. 2014).

Keberadaan NPA pada tanaman padi sudah dilaporkan di Indonesia. Laporan pertama adanya infeksi nematoda puru akar pada tanaman padi terjadi pada tahun 1993 di Yogyakarta yang disebabkan oleh M. graminicola dengan persentase infeksi mencapai 80\% (Erlan 1993). Febriyani (2003) juga melaporkan $M$. graminicola merupakan nematoda penyebab puru akar pada tanaman padi di Bogor. Laporan lain menyebutkan bahwa pertanaman padi di Kecamatan Terisi, Kabupaten Indramayu sudah terinfeksi juga oleh NPA (Sari 2014).

Jawa Barat merupakan salah satu provinsi penyumbang produksi padi terbesar nasional. Berdasarkan laporan dari Kementan (2015), Jawa Barat sebagai salah satu sentra produksi padi nasional urutan ke-2 setelah Jawa Timur selama kurang lebih 5 tahun dengan rata-rata produksi mencapai 11 juta ton per tahun semenjak tahun 2010-2014. Penelitian mengenai keberadaan NPA pada tanaman padi di Jawa Barat perlu diidentifikasi agar upaya pencegahan dan pengendalian dapat dilakukan dengan lebih baik. Oleh karena itu, identifikasi NPA secara morfologi pada tanaman padi di beberapa wilayah di Jawa Barat menjadi tujuan dari penelitian ini.

\section{BAHAN DAN METODE}

\section{Pengambilan Sampel Akar Padi}

Sampel NPA diambil dari pertanaman padi di beberapa daerah di Jawa Barat, yaitu Bogor, Ciamis, Cirebon, Kuningan, Majalengka, Subang, dan Sukabumi. Pengambilan sampel dilakukan dengan metode purpossive sampling, yaitu setiap lahan diambil 10 tanaman yang terlihat terinfeksi NPA. Luas lahan yang diambil berukuran minimal $100 \mathrm{~m}^{2}$. Sampel tanaman padi dicabut dan dimasukkan ke dalam kantong plastik, kemudian disimpan ke dalam kotak pendingin. Proses ekstraksi nematoda dilaksanakan di laboratorium.

\section{Ekstraksi Nematoda}

Ekstraksi nematoda dilakukan berdasarkan metode Hooper et al. (2009). Nematoda diekstraksi dengan metode pengabutan. Akar padi yang terinfeksi NPA dibersihkan dan dipotong-potong $\pm 1 \mathrm{~cm}$. Potongan akar disimpan di atas saringan kasar dan diletakkan di atas corong yang di bagian bawahnya terdapat gelas plastik untuk menampung hasil ekstraksi. Proses ini dilakukan di dalam ruang pengabutan dengan kondisi air melalui nozle dialirkan ke potongan akar. Proses pengabutan dibiarkan selama 48 jam. Setelah itu, gelas plastik yang berisi air disaring dengan menggunakan penyaring 500 mesh. Nematoda yang akan diperoleh adalah larva instar ke-2. Hasil ekstraksi nematoda ini didibuat preparat untuk pengamatan morfologi dan morfometrik larva instar ke-2. 


\section{Preparat Semipermanen}

Preparat semipermanen dibuat berdasarkan metode Goodey (1973). Bagian permukaan atas kaca preparat dibuat cincin parafin menggunakan bor gabus yang dipanaskan. Larutan laktofenol ( $94 \mathrm{~mL}$ fenol, $83 \mathrm{~mL}$ asam laktat, $160 \mathrm{~mL}$ gliserin, dan $100 \mathrm{~mL}$ akuades) diteteskan 1 tetes di tengah lingkaran parafin baru. Nematoda hasil ekstraksi dimatikan di dalam larutan FAA $(10 \mathrm{~mL}$ formalin, $1 \mathrm{~mL}$ asam asetat, $89 \mathrm{~mL}$ akuades) yang telah dipanaskan pada suhu $70{ }^{\circ} \mathrm{C}$ dengan perbandingan volume 1:1. Larva instar ke-2 yang yang telah mati diambil mengait dan memasukkannya ke dalam larutan laktofenol yang berada di cincin parafin. Pada setiap preparat diletakkan sebanyak 3-5 ekor nematoda. Tahap selanjutnya, bagian atas parafin diberi 3 helai glass woll secara radial untuk menahan kaca penutup, kemudian preparat difiksasi sebentar di atas api hingga parafin meleleh. Tahap akhir, bagian tepi kaca penutup yang merekat dengan parafin diolesi perekat menggunakan kuteks kuku agar menjadi kedap udara. Pembuatan preparat semipermanen dilakukan untuk mengamati morfologi dan morfometrik larva instar ke-2.

\section{Pengamatan Morfologi}

Pengamatan morfologi mengikuti prosedur Eisenback dan Hunt (2009). Sebanyak 20 ekor larva instar ke-2 pada preparat semipermanen diamati dan diukur dengan program komputer Dino Capture 2.0, The Versatile Digital Microscope yang tersambung dengan mikroskop cahaya pada perbesaran $100 \times$ dan 400x. Bagian nematoda yang diukur ialah panjang tubuh nematoda, stilet, ekor, diameter tubuh maksimum, nilai a (perbandingan panjang badan/lebar badan maksimum) dan nilai c (perbandingan panjang badan/panjang ekor).

\section{Pewarnaan Nematoda di Akar}

Metode pewarnaan nematoda di dalam akar mengikuti metode Hussey (1985). Metode ini dilakukan untuk mewarnai nematoda yang berada di dalam jaringan akar. Akar padi yang menunjukkan gejala puru dibersihkan dan dipotong-potong dengan ukuran 1-2 cm dan direndam di dalam campuran kloroks $5.25 \%$ selama 4 menit. Selanjutnya, akar dibilas dengan air mengalir selama 45 detik dan direndam dalam air selama 15 menit kemudian dibilas hingga aroma kloroks hilang. Akar direbus dalam larutan fuksin (3.5 g asam fuksin, $250 \mathrm{~mL}$ asam asetat, dan $750 \mathrm{~mL}$ akuades) yang mendidih selama 30 detik dipenangas. Rebusanakardiangkatdan larutan asam fuksin dibuang, kemudian akar dibilas dengan air mengalir. Akar dimasukkan ke dalam botol kecil dan ditambahkan dengan gliserin hingga akar terendam dan ditambah 2 tetes larutan $\mathrm{HCl}$. Selanjutnya akar direbus kembali hingga mendidih dan warna akar terlarut. Akar yang sudah dingin disusun di atas kaca preparat dan diamati nematodanya menggunakan mikroskop cahaya dengan perbesaran 100×.

\section{Pengamatan Pola Perineal}

Metode pengamatan pola perineal mengikuti prosedur Eisenback et al. (1981). Akar padi yang menunjukkan gejala terbentuk puru disimpan di dalam cawan sirakus yang berisi air untuk dibedah dan diambil nematoda betina dewasa. Nematoda betina dewasa diletakkan di atas kaca preparat yang berisi tetesan air. Bagian posterior nematoda dipotong dengan pisau bedah (scalpel blade no. 10) dan dibersihkan dari kotoran. Pada bagian posterior akan terlihat pola perineal yang dapat menentukan spesies Meloidogyne. Bagian pola perineal yang sudah bersih lalu ditutup dengan kaca penutup dan diamati menggunakan mikroskop cahaya pada perbesaran 400x. Jumlah pengamatan pola perineal yang diamati sebanyak 40 ekor nematoda betina dewasa dari masing-masing wilayah.

\section{HASIL}

\section{Gejala Nematoda Puru Akar Padi}

Hasil pengamatan menunjukkan bahwa NPA ditemukan di daerah Bogor, Cirebon, dan Sukabumi. Lahan sawah yang terinfeksi NPA berada dalam keadaan tidak tergenangi 
air (macak-macak). Berdasarkan tampilan luar, tanaman padi yang terinfeksi NPA menunjukkan gejala pertumbuhan agak terhambat dan tidak merata di dalam lahan (Gambar 1a). Beberapa sampel tanaman yang menunjukkan pertumbuhan terhambat dicabut dan diperiksa. Gejala khas tanaman padi yang terinfeksi oleh NPA ialah terbentuknya puru akar. Puru terletak di bagian ujung akar padi yang bengkak dengan membentuk seperti pengait (hook) (Gambar 1b).

Hasil pewarnaan nematoda di dalam akar menampilkan seluruh stadium NPA dengan jelas. Tahap perkembangan stadium NPA dimulai dari pembentukan telur, larva instar ke-2, larva instar ke-3, larva instar ke-4, betina dewasa, dan jantan dewasa (Gambar 2).

Pada bagian anterior dari morfologi larva instar ke-2 terdapat stilet di bagian rongga mulut dan bagian bibir berbentuk set off (Gambar 3a). Bagian luar tubuh nematoda dilapisi oleh kutikula sebagai pelindung. Pada saluran pencernaan terdapat faring yang menghubungkan antara stilet dan median bulb

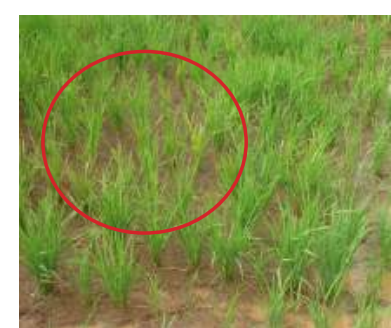

a

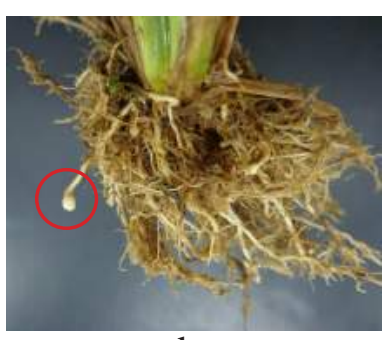

b
Gambar 1 a, Gejala tanaman padi yang terinfeksi nematoda puru akar di Sukabumi dan; b, gejala puru di bagian akar padi. ke bagian pharyngeal gland lobe. Kelenjar faring ini memiliki posisi tumpang tindih dengan usus. Bagian posterior larva instar ke-2 ditandai dengan adanya bagian ekor runcing dengan ujung ekor bulat halus dan terdapat bagian hyaline tail terminus (Gambar 3b).

\section{Morfologi Nematoda Puru Akar}

Ukuran tubuh nematoda larva instar ke-2 dari Bogor, Cirebon, dan Sukabumi bervariasi. Rata-rata panjang tubuh larva instar ke-2 asal Jawa Barat ialah 297.71-321.06 um (Tabel 1). Berdasarkan pada morfologi larva instar ke-2 maka NPA asal Jawa Barat diidentifikasikan sebagai Meloidogyne graminicola. Ciri khas terlihat pada bibir yang berbentuk set off dan ekor runcing dengan bagian ujung ekor bulat halus (Gambar 3).

Pola perineal pada betina dewasa NPA dari akar padi asal Jawa Barat menunjukkan pola yang berbentuk bulat hingga oval dan tidak adanya garis lateral (Gambar 4a). Hal ini diperkuat dengan perbandingan pola perineal M. graminicola asal Nepal (Gambar 4b) yang dilakukan oleh Pokharel et al. (2007). Pola perineal M. graminicola terlihat lebih jelas melalui sketsa seperti yang dilaporkan oleh Hunt dan Handoo (2009) (Gambar 4c).

\section{PEMBAHASAN}

Penemuan $M$. graminicola di Bogor menunjukkan bahwa patogen ini sudah ada sejak lama seperti yang dilaporkan oleh Febriyani (2003). M. graminicola yang ditemukan pada pertanaman padi di daerah

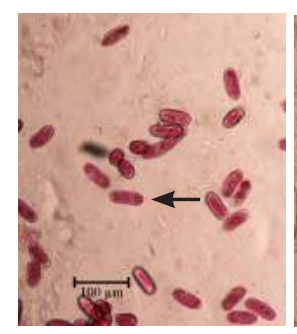

a

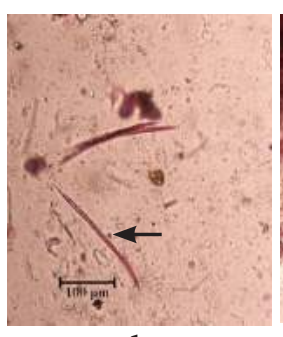

b

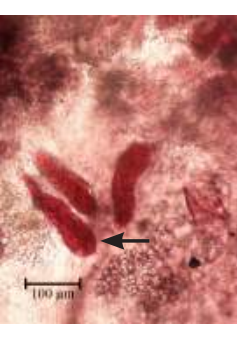

c

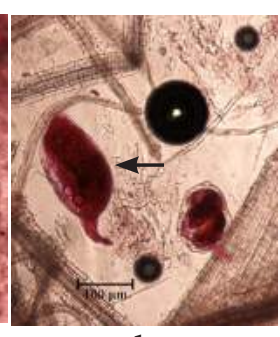

d

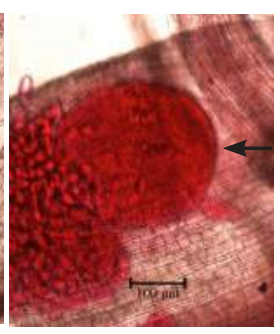

e

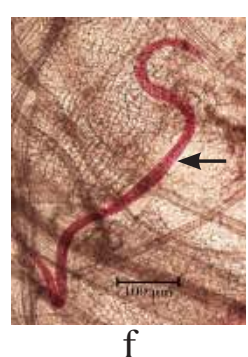

f

Gambar 2 Identifikasi nematoda puru akar (NPA) pada akar tanaman padi dengan perbesaran mikroskop cahaya 40×. a, telur; b, larva instar ke-2; c, larva instar ke-3; d, larva instar ke-4; e, betina dewasa seperti buah pir yang menghasilkan massa telur dan; $f$, jantan dewasa yang keluar dari akar padi. 


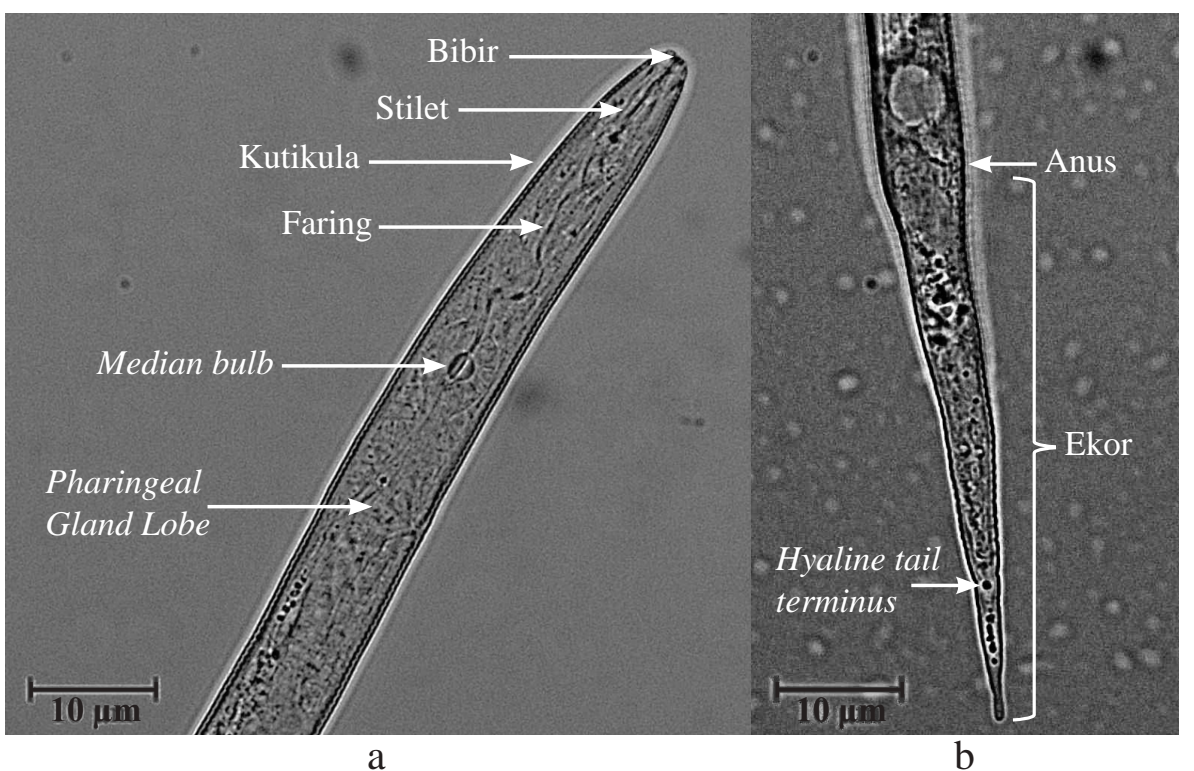

Gambar 3 Morfologi larva instar ke-2 Meloidogyne graminicola dari akar tanaman padi dengan perbesaran mikroskop cahaya $1000 \times$. a, bagian anterior dan; b, bagian posterior.

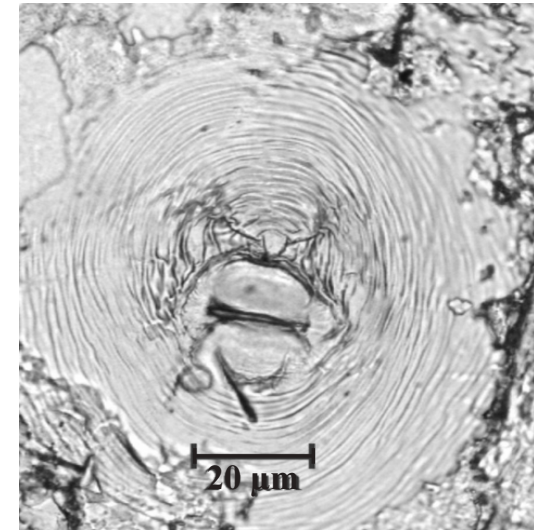

a

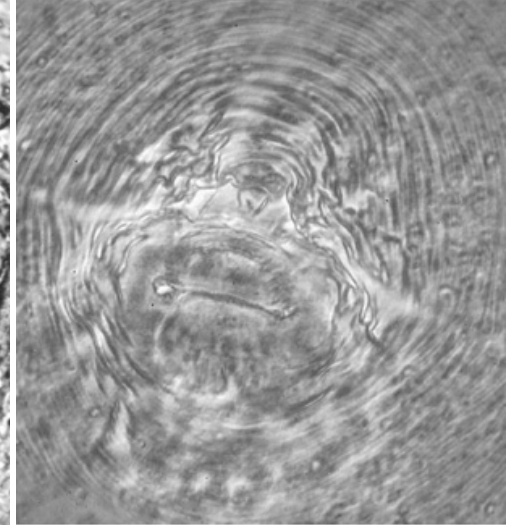

b

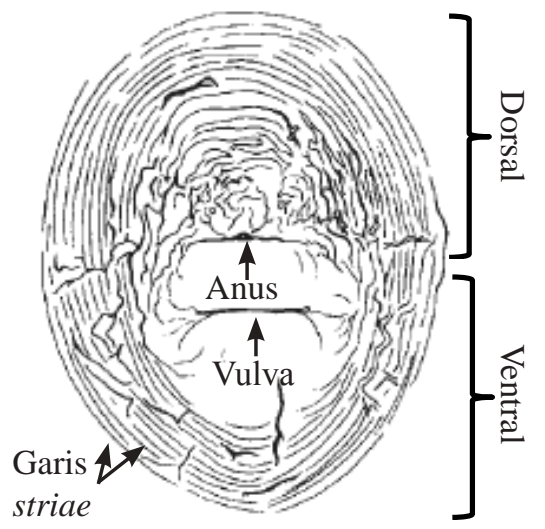

$\mathrm{C}$

Gambar 4 a, Pola perineal Meloidogyne graminicola asal Jawa Barat, Indonesia dengan perbesaran mikroskop cahaya 400×. b, pola perineal M. graminicola asal Nepal (Pokharel et al. 2007) dan; c, sketsa pola perineal M. graminicola (Hunt dan Handoo 2009).

Tabel 1 Perbandingan larva instar ke-2 Meloidogyne graminicola dari akar tanaman padi asal Bogor, Cirebon, dan Sukabumi dengan M. graminicola asal Nepal

\begin{tabular}{lrrrc}
\hline Karakter & \multicolumn{1}{c}{ Bogor $^{\mathrm{a}}$} & \multicolumn{1}{c}{ Cirebon $^{\mathrm{a}}$} & Sukabumi $^{\mathrm{a}}$ & $\begin{array}{c}\text { Nepal (Pokharel } \\
\text { et al. 2007) }\end{array}$ \\
\hline Panjang tubuh $(\mu \mathrm{m})$ & $297.71 \pm 17.95$ & $317.11 \pm 45.72$ & $321.06 \pm 41.07$ & 450.90 \\
Panjang stilet $(\mu \mathrm{m})$ & $9.50 \pm 0.45$ & $9.52 \pm 0.40$ & $9.58 \pm 0.67$ & 11.37 \\
Panjang ekor $(\mu \mathrm{m})$ & $50.10 \pm 2.29$ & $50.54 \pm 3.36$ & $50.52 \pm 2.30$ & 66.36 \\
Lebar badan & $9.88 \pm 0.58$ & $9.85 \pm 0.59$ & $9.87 \pm 0.65$ & 17.34 \\
maksimum $(\mu \mathrm{m})$ & 30.12 & 32.18 & 32.51 & 25.80 \\
Nilai a $^{\mathrm{b}}$ & 5.94 & 6.27 & 6.35 & 6.40 \\
Nilai c $^{\mathrm{c}}$ & & & \\
\hline
\end{tabular}

${ }^{\mathrm{a}} \mathrm{n}, 20$ ekor M. graminicola $;{ }^{\mathrm{b}}$ nilai a, panjang tubuh/lebar badan maksimum;

'Nilai c, panjang tubuh/panjang ekor. 
Bogor, Cirebon, dan Sukabumi diduga berasal dari wilayah luar Jawa Barat. Bridge et al. (2005) menyatakan bahwa $M$. graminicola merupakan patogen tular tanah yang mampu menyebar pada lahan lain karena terjadinya kontak dengan tanah yang terinfestasi NPA. Penyebarannya sangat mudah terjadi, di antaranya melalui tanah maupun bibit persemaian padi yang terinfeksi (Erlan 1993). Awal mula daerah ini mulai terkontaminasi oleh patogen masih belum diketahui dengan pasti. Sejauh ini belum ada hasil penelitian yang dilaporkan.

M. graminicola dapat menginfeksi seluruh jenis padi di berbagai negara di kawasan tropika maupun subtropika. Bridge et al. (2005) melaporkan M. graminicola memiliki distribusi yang luas pada tanaman padi gogo, padi sawah tadah hujan, dan padi sawah irigasi di Asia Selatan dan Asia Tenggara. Hampir semua varietas tanaman padi yang digunakan petani di Jawa Barat merupakan varietas yang rentan. Varietas Ciherang, Cisadane, Pelita, Waiseputih, IR33, IR36 dan IR64 telah terbukti mudah terinfeksi oleh $M$. graminicola (Erlan 1993; Febriyani 2003).

Pada umumnya jenis tanah yang digunakan untuk menanam padi di daerah Jawa Barat ialah tanah liat/lempung. Teknik penanamannya dilakukan dengan penggenangan air. $M$. graminicola tetap mampu menginfeksi akar tanaman padi di dalam tanah berlempung ketika kondisi sawah tidak tergenang air atau macak-macak, namun persebaran patogen ini tidak meluas dengan cepat terhadap lahan lainnya. Larva instar ke-2 nematoda ini lebih mudah bergerak dan menginfeksi akar di dalam tanah berpasir yang tidak tergenangi air. Kondisi tanah berpasir memungkinkannya cepat menyebar pada tanaman lainnya. Selain faktor jenis tanah dan teknik penggenangan, kondisi musim kemarau mampu meningkatkan populasi $M$. graminicola di dalam jaringan akar dibandingkan dengan musim hujan (Erlan 1993).

Keberadaan $M$. graminicola dapat ditentukan dengan ekstraksi akar, pewarnaan akar dan pengamatan pola perineal dari dalam akar padi. Larva instar ke-2 merupakan stadium yang bersifat infektif terhadap jaringan akar. Stadium larva instar ke-2 masuk ke dalam jaringan dengan bergerak secara intersel menuju jaringan pembuluh dan membentuk giant cell untuk menyimpan nutrisi. Fase larva instar ke-2 akan berubah menjadi larva instar ke-3 dan ke-4 yang kemudian menjadi fase dewasa. Fase betina dewasa hidup sebagai parasit menetap (sedentary endoparasite) di dalam jaringan dengan mengambil nutrisi melalui giant cell (Abad et al. 2009).

Larva instar ke-2 asal Jawa Barat berbeda dengan larva instar ke-2 dari $M$. graminicola asal Nepal. Perbedaan yang terlihat jelas ialah pada ukuran panjang tubuh larva instar ke-2. Nematoda dari Jawa Barat, Indonesia lebih kecil dibandingkan dengan dari Nepal yang memiliki kisaran rata-rata $450.9 \mu \mathrm{m}$. Perbedaan panjang tubuh larva instar ke-2 ini diduga karena adanya perbedaan geografi. Perbedaan tersebut kemungkinan disebabkan oleh faktor-faktor yang masih belum diketahui.

Identifikasi M. graminicola dapat diperkuat melalui hasil pengamatan pola perineal betina dewasa. Pola perineal yang terbentuk memiliki ciri yang khas, yaitu berbentuk bundar atau oval. Bagian garis striae membentuk garis yang teratur dan halus, sedangkan garis lateral tidak terlihat (Hunt dan Handoo 2009). Yik dan Birchfield (1978) menyatakan bahwa pola perineal $M$. graminicola berdasarkan pengamatan mikroskop elektron pemindai memiliki garis striae yang halus dan garis bagian luar tebal dengan pola berbentuk oval. Bagian dorsal menuju vulva, garis striae saling terhubung membentuk tetragonal atau piramida yang terpusat pada ekor terminus. Masing-masing bagian sudut celah vulva memiliki striae yang berbentuk semi bulat yang tersusun atas dua atau tiga striae. Seluruh betina dewasa memiliki bibir vulva halus tanpa adanya invaginasi. Kutikula striae yang berbentuk tetragonal atau piramida merupakan ciri pembeda terhadap spesies Meloidogyne lainnya selain dari bentuk pola perineal yang oval atau bulat.

Hasil penelitian ini menunjukkan bahwa NPA yang menginfeksi tanaman padi di daerah Jawa Barat (Bogor, Cirebon dan Sukabumi) 
ialah M. graminicola. Informasi ditemukannya $M$. graminicola pada pertanaman padi di wilayah ini sangat penting diketahui agar selanjutnya dilakukan pencegahan sehingga patogen ini tidak menyebar lebih luas di wilayah lainnya. Daerah yang telah terinfeksi dapat dilakukan upaya pengendalian yang efektif, yaitu melakukan penggenangan terhadap tanaman padi sampai panen (Negretti et al. 2014) dan pemberian bahan organik yang cukup (Dangal et al. 2008).

\section{DAFTAR PUSTAKA}

Abad P, Castagno-Sereno P, Rosso MN, Engler JA, Favery B. 2009. Invasion, feeding and development. Di dalam: Perry RN, Moens M, Starr JL, editor. Root Knot Nematodes. Cambridge (US): CABI. hlm 163-176. DOI: http://dx.doi. org/10.1079/9781845934927.0163.

Bridge J, Plowright RA, Peng D. 2005. Nematode parasite of rice. Di dalam: Luc M, Sikora RA, Bridge J, editor. Plant Parasitic Nematodes in Subtropical and Tropical Agriculture. Ed ke-2. London (UK): CABI Publishing. hlm 87-130. DOI: http:// dx.doi.org/10.1079/9780851997278.0087.

Dangal NK, Sharma-Poudyal D, Shrestha SM, Adhikari C, Duxbury JM, Lauren JG. 2008. Evaluation of organic amendments against rice root-knot nematode at seedling stage of rice. Nepal J Sci Technol. 9:21-27.

Dutta TK, Ganguly AK, Gaur HS. 2012. Global status of rice root rice root knot nematode, Meloidogyne graminicola. Afr J Microbiol Res. 6(31):6016-6021. DOI: 10.5897/AJMR 12.707. DOI: http://dx.doi. org/10.5897/AJMR.

Eisenback JD, Hirschman H, Sasser JN., Triantaphyllou AC. 1981. A Guide to the Four Most Common Species of Root-Knot Nematodes (Meloidogyne spp.), with A Pictorial Key. North Carolina (US): North Carolina State University and U.S Agency International Development.

Eisenback JD, Hunt DJ. 2009. General morphology. Di dalam: Perry RN, Moens M, Starr JL, editor. Root
Knot Nematodes. Cambridge (US): CABI. hlm 18-50. DOI: http://dx.doi. org/10.1079/9781845934927.0018.

Erlan. 1993. Distribusi dan patogenisitas nematoda Meloidogyne cf. graminicola pada tanaman padi sawah di Daerah Istimewa Yogyakarta [tesis]. Yogyakarta (ID): Universitas Gajah Mada.

Febriyani D. 2003. Nematoda puru akar (Meloidogyne spp.) pada tanaman padi sawah di Kelurahan Situ Gede, Bubulak, Kecamatan Bogor Barat dan Desa Caringin, Kecamatan Darmaga, Bogor [skripsi]. Bogor (ID): Institut Pertanian Bogor.

Goodey T. 1973. Two methods for staining nematodes in plant tissue. $\mathrm{J}$ Helminthol. 15:137-144. DOI: http://dx.doi. org/10.1017/S0022149X00030790.

Hooper DJ, Hallmann J, Subbotin SA. 2005. Methods for extraction, processing and detection of plant and soil nematodes. Di dalam: Luc M, Sikora RA, Bridge J, editor. Plant Parasitic Nematodes in Subtropical and Tropical Agriculture. Ed ke-2. London (UK): CABI. hlm 53-86. DOI: http:// dx.doi.org/10.1079/9780851997278.0053.

Hunt DJ, Handoo ZA. 2009. Taxonomy, identification, and principal species. Di dalam: Perry RN, Moens M, Starr JL, editor. Root Knot Nematodes. Cambridge (US): CABI. hlm 55-88. DOI: http:// dx.doi.org/10.1079/9781845934927.0055.

Hussey RS. 1985. Staining nematodes in plant tissue. Di dalam: Zuckerman BM, Mai WF, Harrison MB, editor. Plant Nematology, Laboratory Manual. Massachusetts (US): University of Massachusetts Agricultural Experiment Station Amherst.

Jaiswal IRK, Singh KP, Mishra RK. 2011. A Technique for the detection of soil infestation with rice root-knot nematode, Meloidogyne graminicola at farmer's field. Acad J Plant Sci. 4 (4):110-113.

Kementrian Pertanian. 2015. Produksi padi sawah tahun 2010-2014. http://aplikasi. pertanian.go.id/bdsp/hasil_lok.asp [diakses 4 Mei 2015].

Negretti RRD, Manica-Berto R, Agostinetto D, Thurmer L, Gomes CB. 2014. Host 
suitability of weeds and forage species to root knot nematode Meloidogyne graminicola as a function of irrigation management. Planta Daninha. 32(3):555561.

Nguyen PV, Bellafiore S, Petitot AS, Haidar R, Bak A, Abed A, Gantet P, Mezzalira I, Engler JA, Fernandez D. 2014. Meloidogyne incognita-rice (Oryza sativa) interaction: a new model system to study plant-root knot nematode interactions in monocotyledons. Rice. 7:23:1-13. DOI: http://dx.doi.org/10.1186/s12284-0140023-4.

Padgham JL, Duxbury JM, Mazid AM, Abawi GS, Hossain M. 2004. Yield loss caused by Meloidogyne graminicola on lowland rainfed rice in Bangladesh. $\mathrm{J}$ Nematol. 36(1):42-48.

Pokharel RR, Abawi GS, Zhang N, Duxbury JM, Smart CD. 2007. Characterization of isolates of Meloidogyne from rice-wheat production fields in Nepal. J Nematol. 39(3):221-230.

Sari FNI. 2014. Nematoda parasit padi sawah di Kecamatan Terisi, Kabupaten Indramayu [skripsi]. Bogor (ID): Institut Pertanian Bogor.

Yik CP, Birchfield W. 1978. Host studies and reaction of rice cultivars to Meloidogyne graminicola. Am Phytopathol Soc. 69(5):497-499. DOI: http://dx.doi. org/10.1094/Phyto-69-497. 